\title{
Got shrubs? Precipitation mediates long-term shrub and introduced grass dynamics in chaparral communities after fire
}

\author{
April G. Smith ${ }^{1 *}$, Beth A. Newingham ${ }^{1}$, Andrew T. Hudak ${ }^{2}$ and Benjamin C. Bright ${ }^{2}$
}

\begin{abstract}
Background: Short-term post-fire field studies have shown that native shrub cover in chaparral ecosystems negatively affects introduced cover, which is influenced by burn severity, elevation, aspect, and climate. Using the southern California 2003 Old and Simi fires and the 2008 Sesnon Fire, we investigated the role of native shrubs in post-fire ecosystem responses across gradients of elevation, aspect, climate, burn severities, fire histories, and time. We collected field estimates of species cover in 2004 and 2015 at nested sampling sites. We used structural equation models with introduced and shrub cover as dependent variables.

Results: Shrub cover in 2004 was most influenced by the number of reburns, while shrub cover in 2015 was most influenced by the time between the two most recent fires. In 2004, introduced cover was most influenced by burn severity in 2003; similarly, in 2015, introduced cover was most influenced by burn severity in 2008. In both one and twelve years post fire, average precipitation increased the length of time between fires and decreased the number of times a site burned. This direct reduction in the number of times a site had burned due to average precipitation resulted in lower shrub cover one and twelve years post fire. Additionally, mean annual precipitation increased burn severity one year post fire, which resulted in lower introduced cover. However, this indirect relationship between precipitation and introduced cover through burn severity was no longer present twelve years post fire. Shrub cover increased with a longer average time between fires twelve years after fire. Shrub cover did not mediate any indirect relationships between burn severity or fire history metrics and introduced cover in either year, suggesting competitive exclusion of introduced species by shrubs.
\end{abstract}

Conclusion: Our research found that significant fire effects on shrub and introduced species are often mediated by precipitation. Precipitation trends are likely to change fire regimes and thus alter plant community dynamics.

Keywords: burn severity, community dynamics, invasion, post fire, reburn, structural equation modeling (SEM)

\footnotetext{
* Correspondence: aprilgracesmith@gmail.com

${ }^{1}$ USDA Agricultural Research Service, Great Basin Rangelands Research Unit,

920 Valley Road, Reno, Nevada 89512, USA

Full list of author information is available at the end of the article
} 


\section{Resumen}

Antecedentes: Estudios de campo sobre los efectos post-fuego de corto plazo mostraron que la cobertura de arbustos en ecosistemas de chaparral afectan negativamente la cobertura de especies introducidas, las cuales son influenciadas por la severidad del fuego, la elevación, la exposición, y el clima. Usando datos de los incendios de 2003, Ilamados Old y Simi, y del de 2008 llamado Sesnon, ocurridos en el sur de California, investigamos el rol de los arbustos nativos en la respuesta post-fuego del ecosistema a través de gradientes de elevación, exposición, clima, severidad del fuego, historias de fuego, y el tiempo cronológico. Estimaciones de cobertura de especies fueron colectadas a campo en 2004 y en 2015, mediante muestreos anidados en diferentes sitios. Usamos modelos de ecuaciones estructurales con cobertura de especies introducidas y de arbustos, como variables dependientes.

Resultados: La cobertura de arbustos en 2004 fue mayormente influenciada por la repetición en el número de incendios, mientras la cobertura de arbustos en 2015 fue mayormente influenciada por el tiempo entre los dos incendios más recientes. En 2004, la cobertura de especies introducidas fue mayormente influenciada por la severidad del incendio en 2003; similarmente en 2015, la cobertura de introducidas fue mayormente influenciada por la severidad del incendio en 2008. En ambos uno y doce años después del fuego, la precipitación media incrementó la duración del intervalo de tiempo entre fuegos, e hizo decrecer el número de veces en que se quemó un mismo sitio. Esta reducción directa en el número de veces que un mismo sitio se quemó debido a incrementos en la precipitación media, resultó en una menor cobertura de arbustos desde uno y hasta doce años post-fuego. Adicionalmente, la precipitación media anual incrementó la severidad del fuego un año después de ocurrido, lo que resultó en una menor cobertura de especies introducidas. Sin embargo, esta relación indirecta entre precipitación y cobertura de especies introducidas mediada por la severidad del fuego, no estuvo presente doce años después del fuego. La cobertura de arbustos se incrementó con un espaciamiento temporal entre fuegos doce años después del fuego. La cobertura de arbustos no tuvo ningún efecto mediador o relación indirecta entre la severidad del fuego o la historia de eventos de fuego y la cobertura de especies introducidas en cada año, lo que sugiere una exclusión competitiva de especies introducidas por parte de los arbustos nativos.

Conclusiones: Nuestra investigación encontró que los efectos significativos del fuego en arbustos nativos y especies introducidas, son frecuentemente mediados por la precipitación. Las tendencias de la precipitación probablemente cambien los regímenes de fuego y por lo tanto alteren la dinámica de las comunidades vegetales.

\section{Background}

Plant community dynamics after fire are influenced by a suite of factors, including climate, fire characteristics, and non-living groundcover. Post-fire precipitation can affect plant community responses to fire by altering plant growth and survival, resulting in changes in plant community composition and successional trajectories (Keeley et al. 2005b). Additionally, plant establishment after fire can be influenced by non-living groundcover, such as litter, rock, and bare ground. For example, high litter and rock cover may limit post-fire soil erosion (Shakesby et al. 1994) and provide microsites for seed germination (Schlesinger and Gill 1978). Local conditions, such as burn severity, most recent fire return interval, as well as plant canopy, can also affect soil heating, reducing the seed bank and fuel load for subsequent fires (Odion and Davis 2000). Fire characteristics, such as burn severity, can impact future plant communities by affecting fire behavior and effects within subsequent fires (Parks et al. 2014a). Furthermore, repeat burns may affect a site's invasibility and thus ecosystem trajectory (Keeley and Brennan 2012).
Historically, wildfire in chaparral ecosystems burned with high severity through closed shrub canopies (Borchert and Odion 1995, Keeley and Fotheringham 2001) every 30 to 150 years (Van de Water and Safford 2011), generally from July to August, with lightning as the primary ignition source (Keeley and Fotheringham 2001). At 15 years post fire, leaf area index is maximized, and shrubs can burn with high intensity, resulting in stand-replacing crown fires (McMichael et al. 2004). The chaparral biotic community evolved with these strong selective pressures under its historical fire regime (Keeley et al. 2011). However, the historical fire regime has changed due to fire suppression, the introduction of non-native plant species, urban growth into previously shrub-dominated landscapes, both humancaused ignitions and climate change extending the fire season to year-round, and increasing fire size and frequency (D’Antonio and Vitousek 1992; Moritz 2003; Keeley et al. 2005c; Van de Water and Safford 2011; Molinari et al. 2018; Syphard et al. 2018a, 2018b). These changes to the historical fire regime have led to changes in the structure, function, and range of the 
chaparral plant community (Bond and Keeley 2005, Molinari et al. 2018).

Pre-fire plant communities may also influence how a post-fire plant community responds to wildfire. In chaparral, shrubs are highly flammable due to high resin content, woody stems, standing dead branches, and the accumulation of litter beneath their bases. Some shrub species are adapted to survive high-severity fires either by resprouting (obligate resprouter), having high seed survival in the seed bank (obligate reseeder), or both (facultative seeder). Areas that burn more frequently are at a higher risk of extirpating the native plant community in favor of introduced species, as many native shrubs cannot survive frequent fires. For example, Adenostoma fasciculatum Hook. \& Arn. will not resprout without an adequate growth period between fires (Zedler et al. 1983). Increases in fire frequency may lead to lower burn severity during subsequent fires and thus higher introduced species invasion (Keeley et al. 2005d, Keeley et al. 2008).

Following a fire, succession in the plant community is dominated by residual species that survived the disturbance either by resprouting or germinating from the seed bank. Colonizers also play an essential role in the biodiversity of early post-fire communities and typically arrive onto a site in the first or second growing season. Short-term field studies after fire in chaparral ecosystems have shown that native shrub cover is negatively associated with both introduced forb and graminoid cover, and that introduced species are influenced by burn severity, elevation, aspect, and precipitation (Keeley et al. 2005a, Grace and Keeley 2006, Lentile et al. 2007). Specifically, Keeley et al. (2005a) found that alien cover is negatively associated with woody plant cover five years after fire. In early post-fire years, shrubs are the primary functional group to both resprout and germinate in chaparral communities (Keeley et al. 2005a). However, introduced annual grasses are also rapid post-fire colonizers (D'Antonio and Vitousek 1992). Therefore, the dynamic between shrub and annual grass establishment is likely to determine long-term successional trajectories.

Few to no studies have examined the direct and indirect relationships between fire history, burn severity, years between fires, non-living groundcover, time, and precipitation that mediate post-fire chaparral community dynamics. Using hypothesized relationships, as well as other studies, we created a structural equation model (SEM) to understand the relationships between these variables (Fig. 1, Table 1). SEM's are a powerful statistical tool designed to determine causal multivariate relationships and uniquely allow for examining simultaneous multivariate relationships (Grace and Keeley 2006, Dell et al. 2017). We examined these relationships in a relatively intact montane chaparral ecosystem that burned typical of past chaparral fire regimes, as well as in an interior chaparral ecosystem that has had more frequent fires and a greater invasion of non-native species. We hypothesized that: 1) the amount of precipitation would directly affect burn severity and fire history, as well as shrub and introduced species cover; 2) fire history metrics (time between the most recent two fires and number of reburns) would indirectly affect shrub and introduced species cover; and 3) shrub species would adversely affect introduced species, as mediated by precipitation, burn severity, fire history metrics, and non-living groundcover variables. Using SEM to evaluate species responses across interacting burn severity, fire return interval, precipitation, and invasion gradients may provide insight into post-fire successional trajectories.

\section{Methods}

\section{Study sites}

The Simi Fire was a 43 789-ha (108 204-acre) fire that burned in the Santa Susanna Mountains north of Simi Valley in southern California, USA, from 25 October to 5 November 2003. Study sites ranged in elevation from 532 to $772 \mathrm{~m}$, mean annual temperature ranged from 16.1 to $17.3^{\circ} \mathrm{C}$, and mean annual precipitation from 462 to $486 \mathrm{~mm}$ (Fig. 2) from 2003 to 2010. True to interior chaparral ecosystems, Simi sites did not have trees; the dominant native plant species were Adenostoma fasciculatum Hook. \& Arn., Lupinus sparsiflorus Benth., Cryptantha muricata Hook. \& Arn., Brassica nigra L., and Ceanothus oliganthus Nutt. Introduced species at the Simi sites included Bromus diandrus Roth, Bromus madritensis L., and Bromus rubens L. Areas of the Simi Fire reburned in the Sesnon Fire, which burned 5949 ha (14. 700 acres) from 13 to 18 October 2008.

The Old Fire was a 36940-ha (91281-acre) fire that burned in the San Bernardino Mountains in southern California, USA, from 25 October to 2 November 2003. Sites ranged in elevation from 1408 to $1559 \mathrm{~m}$; mean annual temperature ranged from 12.3 to $13.4{ }^{\circ} \mathrm{C}$ from 2003 to 2010, and mean annual precipitation from 369 to 443 mm (Fig. 2). Overstory in this montane chaparral ecosystem was dominated by Quercus kelloggii Newberry and Quercus chrysolepis Liebm. The primary native understory vegetation was Ceanothus incanus Torr. \& A. Gray, Ceanothus greggii A. Gray var. vestitus (Green) McMinn, Arctostaphylos glandulosa Eastw., and Eriodictyon crassifolium Benth. Introduced species at the Old Fire sites were Bromus tectorum L. and Erodium cicutarium $\mathrm{L}$.

\section{Field measurements}

Immediately after the 2003 fires, Burn Area Reflectance Classification maps (Clark et al. 2003) were used to select six sites across burn severity levels (low, moderate, 


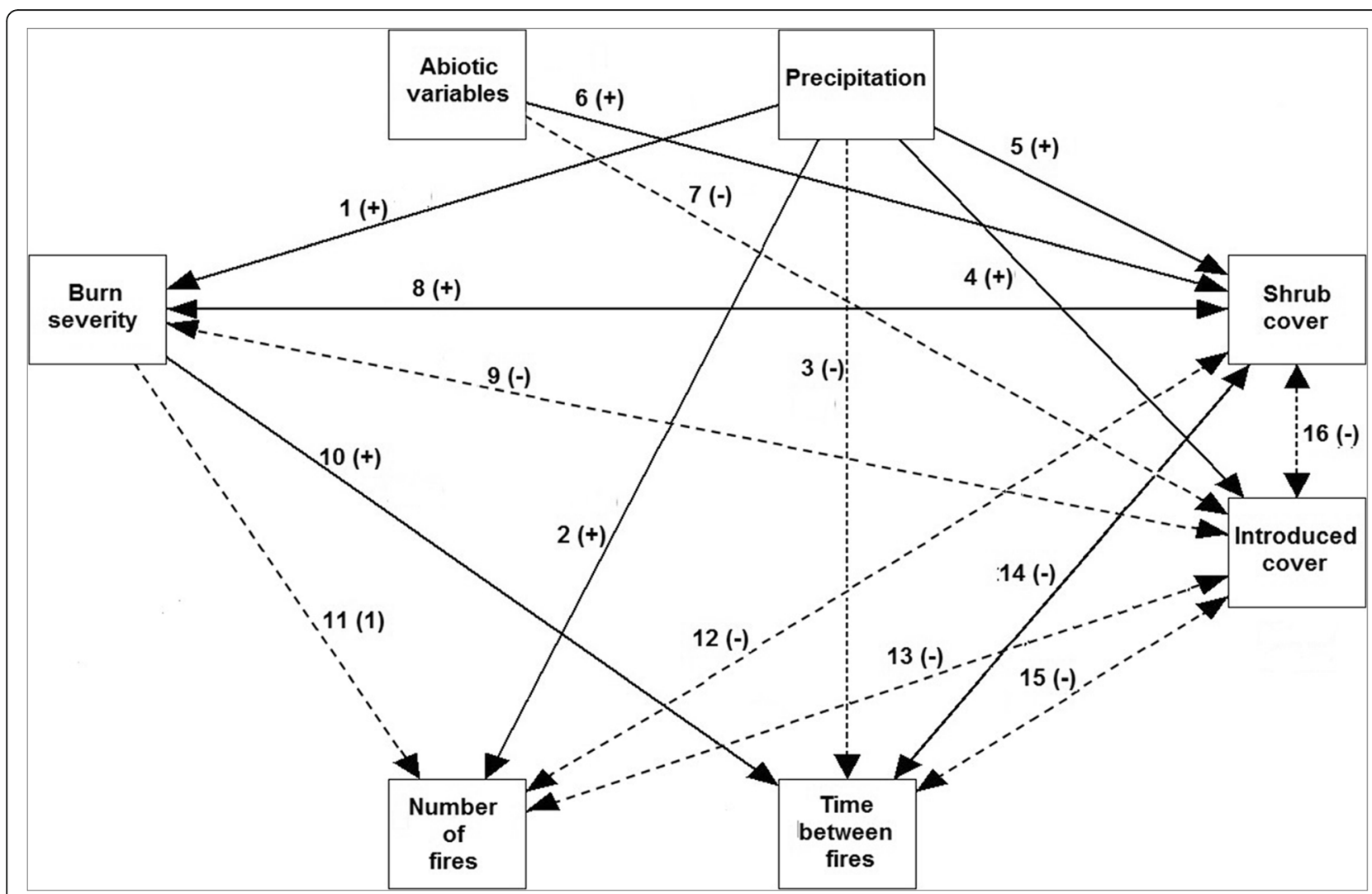

Fig. 1 A conceptual model of hypothesized relationships (Table 1) among variables in post-fire plant community dynamics in southern California, USA, chaparral communities in 2004 and 2015. Path arrows indicate the direction of the relationship between variables. Double-headed path arrows indicate variables that influence each other. Path numbers and directionality are described in Table 1. Positive relationships are displayed with solid lines and negative relationships with dashed lines

Table 1 Components of hypothesized relationships (Fig. 1) represented by initial structural equation model. The model represents post-fire plant community dynamics in southern California, USA, chaparral communities one year and twelve years after the 2003 Old and Simi fires

\begin{tabular}{ll}
\hline Path & Hypothesized relationship \\
\hline 1 & (+) Fire severity increases with fuel moisture (Parks et al. 2014b). \\
2 & (+) Precipitation increases the number of fires at a site by increasing site productivity and thus fuel loads (Davis and Michaelsen 1995). \\
3 & (-) Wetter sites are less likely to burn with a short time interval between fires (Meng et al. 2014). \\
4 & (+) Resource fluctuations, particularly increases in precipitation, lead to increases in plant diversity (Keeley et al. 2005b). \\
5 & (+) Leaf area index increases with increases in antecedent precipitation conditions (McMichael et al. 2004). \\
6 & (+) Rocky topography provides favorable microsites for young shrub stands (Schlesinger and Gill 1978). \\
7 & (-) Persistent negative relationships between introduced species richness and rock cover were found over five years (Keeley et al. 2005d). \\
8 & (+) Fire severity is high where plant cover is high (Grace and Keeley 2006). \\
9 & (-) The relationship between dNBR and non-native cover is negative (Lentile et al. 2007). \\
10 & (+) Burn severity increases with the length of time since the last burn (Parks et al. 2014a). \\
11 & (-) Fire severity is significantly lower when fires burn within a previously recorded fire perimeter (i.e., it reburned; Parks et al. 2015). \\
12 & (-) Fire frequency (<12 yr) limits shrub recruitment (Jacobsen et al. 2004). \\
13 & (-) Sites that burn twice in four years have higher introduced cover then sites that burn once in four years (Keeley and Brennan 2012). \\
14 & (+) Shorter fire intervals increase gap size and decrease shrub cover, negatively effecting shrub cover (Jacobsen et al. 2004). \\
15 & (-) Introduced cover increases with younger pre-fire stand age (Keeley et al. 2005d). \\
16 & (-) A direct negative relationship exists between woody plant canopy and introduced species dominance (Keeley et al. 2005d). \\
\hline
\end{tabular}




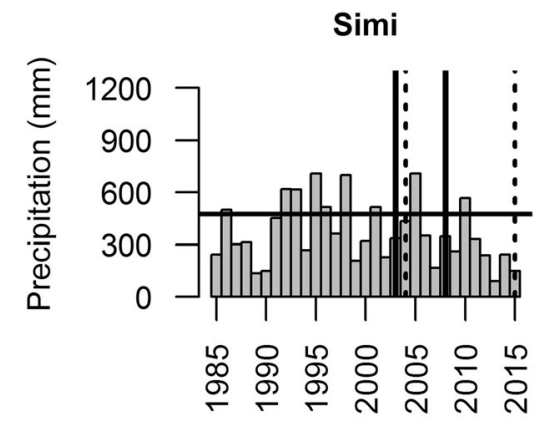

Year
Old

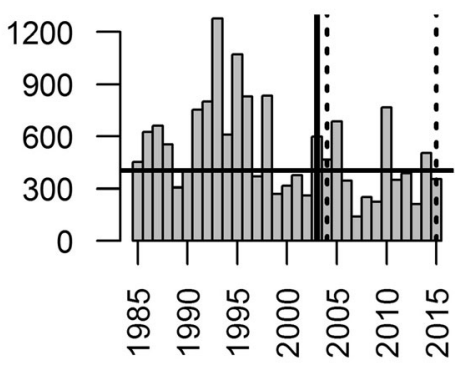

Year

Fig. 2 Annual precipitation at the Simi and Old fires in southern California, USA, spanning the time before the fires through the second survey year. Survey years are indicated with dashed vertical lines and the year of the fires with solid vertical lines. Horizontal lines represent the average mean annual precipitation calculated from 2003 to 2010

or high) at each fire, with designations verified by field observations of vegetation canopy condition; predominantly green, brown, or black vegetation crowns were considered to be burned at low, moderate, or high severity, respectively (Hudak et al. 2007). Prior to 2015 field sampling, the burn areas were stratified by burn severity level, elevation, and transformed aspect (Roberts and Cooper 1989); two additional sites were added at the Simi Fire to fill two strata not represented by the initial field sites. Five $1 \mathrm{~m}^{2}$ plots were sampled within each $60 \times 60 \mathrm{~m}$ site; four plots were placed around a central plot in orthogonal directions oriented with the prevailing slope and plots were spaced $30 \mathrm{~m}$ apart to include three to four adjacent Landsat satellite image pixels. The center plot was monumented, and the sites were revisited in 2004 and 2015 (Bright et al. 2019).

Understory vascular plant cover was ocularly estimated at each plot; cover included tree seedlings and saplings less than $1.37 \mathrm{~m}$ in height. All plants were identified to species, genus, or family. Each plant identified was assigned to a functional group (forbs, graminoids, shrubs, or trees) and designated as either native or introduced based on the USDA PLANTS Database (USDA NRCS 2016).

\section{Statistics}

A conceptual model to integrate the relationships among burn severity, fire history metrics, climate, plant community, and abiotic variables was developed from preliminary analyses and previous studies (Fig. 1). Based on this conceptual model, we tested direct and mediated (indirect) relationships between our collected variables (Grace 2006). Variables included in the hypothesized model were first examined for normality using the Shapiro-Wilks test of normality and then examined for skewness and kurtosis. All variables failed the Shapiro-Wilks test for normality $(P$ $<0.05)$. To account for non-normality, the variable standard error and structural equation model test statistic were calculated by bootstrapping with repetitions set to 1000 . Estimates of direct relationships were calculated using the lavaan package version 0.5-23.1097 (Rosseel 2012) in R version 3.5.0 ( $\mathrm{R}$ Core Team 2018). Estimates and significance of the mediated relationships were also obtained using the lavaan package by explicitly defining interactions of interest using the test for mediation as outlined by Grace (2006). To account for the two sites that were added to the Simi Fire in 2015, we used full information maximum likelihood estimation. Autocorrelation among plots within sites was tested using Moran's I (Plant 2012); we found no autocorrelation, so the plot was used as the replicate throughout this study.

Correlations in the model residuals were computed from the SEM. Correlations in model residuals $(<0.10)$ were then evaluated for exclusion by comparing the Akaike information criterion (AIC) of models with and without the variable. If no significant reduction in AIC was found by excluding the variable, the more parsimonious model was kept. Next, correlations between variable errors were evaluated using modification indices; errors with indices greater than 3.84 were included in the model. Competing models were evaluated for a significant reduction in AIC. The final model fit was evaluated for acceptability based on no significant difference between the expected and observed covariance, a comparative fit index of 0.90 to 1.00 , and root mean square error of 0.00 to 0.10 . Direct relationships were significant when $P<0.05$. Significant bivariate relationships found in SEM were further examined using Spearman rank correlation coefficients.

For fire history information, we obtained CalFire's fire history GIS layer. This was used to determine how many times a site had burned since 1878, which is when the database records began (CalFire 2017). From this we calculated the time between the two most recent fires and the number of times a site had burned. These two metrics were used in the subsequent analysis to represent 
fire history and are referred to as fire history metrics throughout text. We tallied the number of fires and time between the two most recent fires one year after the Old and Simi fires (2004), and again in 2015, which captured the Sesnon Fire reburning some of the Simi Fire sites. To indicate burn severity, we used differenced normalized burn ratio (dNBR), which was generated from Landsat 5 Thematic Mapper imagery (Hudak et al. 2007). The dNBR was calculated in 2003 for the Old and Simi fires and again in 2008 for the Sesnon Fire.

Climate variables were interpolated at $1 \mathrm{~km}$ resolution using a thin-plate spline model (Hutchinson 2000) of the western United States (Rehfeldt 2006, Rehfeldt et al. 2015). To capture finer scale variation in climate $(30 \mathrm{~m})$, we applied the model, which was based on a resolution of $\sim 1 \mathrm{~km}$, to annual climatic data for the years 1981 to 2010 using the digital elevation model from the Shuttle Radar Topographic Mission (Farr et al. 2007). At each plot, climate normals were extracted and calculated from 2003 to 2010, including mean annual temperature, mean annual precipitation, mean maximum temperature in the warmest month, mean minimum temperature in the coldest month, growing season precipitation (Apr to Sep), winter precipitation (Nov to Feb), summer precipitation (Jul to Aug), and spring precipitation (Apr to May).

We calculated residuals for the climate normals at each fire separately by subtracting the mean at each fire to account for site differences. Spearman correlation coefficients and corresponding $P$-values were obtained for the relationships between all climate variables. All climate variables were highly correlated. Unlike temperature, chaparral fire occurrence is directly dependent on precipitation variability (Dennison and Moritz 2010), and this variability can mitigate modeled temperature changes under future climate scenarios (Bachelet et al. 2016). Thus, mean annual precipitation residuals were selected to broadly represent climate (Fig. 2).

Three field-collected abiotic variables were evaluated using Spearman's correlation tests for inclusion in the model: percentage cover of litter, rock, and bare ground. Litter and bare ground (2015: $\mathrm{r}=-0.43, P=0.0002$ ), rock and bare ground (2015: $\mathrm{r}=0.43, P<0.0001)$, and rock and litter (2015: $\mathrm{r}=-0.45, P<0.0001)$ were significantly correlated. Bare ground was removed from consideration due to its correlation with litter and rock. Litter cover was removed from consideration as it was significantly correlated with other plant metrics (introduced cover 2015: $\mathrm{r}=0.41, P=0.0004)$. Rock cover was thus selected as the non-living ground cover variable to include in the model.

Throughout the text and figures, variables are labeled with the year the data was collected. For example, time between the two most recent fires in 2004 used a data set that included all fires up to 2004, while time between the two most recent fires in 2015 used a dataset that included all fires up to 2015.

\section{Results}

\section{Community relationships}

Shrub cover after the Old and Simi fires ranged from 0 to $75 \%$ in 2004 and 0 to $95 \%$ in 2015 (Additional file 1, Fig. 1). In 2004, the most common species were Adenostoma fasciculatum, Arctostaphylos glandulosa, Eriodictyon crassifolium, Ceanothus crassifolius Torr., and Ceaonothus cordulatus Kellog (Additional file 2, Table 1). All but one of these most common species in 2004 is a facultative seeder; Ceanothus crassifolius is an obligate seeder. Together, these species made up $75 \%$ of shrub species cover and $25 \%$ of total species cover. In 2015, the most common species were Adenostoma fasciculatum, Ceanothus incanus, Ceanothus greggii var. vestitus, Ceanothus oliganthus, Malosma laurina (Nutt.) Nutt. ex Abrams, Quercus chrysolepis, Eriogonum fasciculatum Benth., Artemisia californica Less., and Ceanothus leucodermis Greene (Additional file 2, Table 1). Together, these species made up 76\% of the shrub cover and 32\% of total species cover. The shrubs with high cover in 2015 were all facultative seeders except Ceanothus greggii var. vestitus, which is an obligate seeder.

Introduced cover after the Old and Simi fires ranged from 0 to $100 \%$ in both 2004 and 2015 (Additional file 1, Fig. 1). In 2004, the most common species were Bromus diandrus, Briza maxima L., and Brassica nigra (L.) W.D.J. Koch (Additional file 2, Table 1. Together, these three species made up $22 \%$ of total species cover and $71 \%$ of introduced cover; the remaining eight introduced species (Avena sp. L., Erodium cicutarium, Bromus tectorum, Avena fatua L., Arabis glabra [L.] Bernh., Atriplex sp. L., Solanum sarrachoides Rusby, and Nicotiana glauca Graham) made up the remaining 29\% of introduced cover. In 2015, the most common introduced species were Bromus diandrus, Bromus tectorum, Erodium cicutarium, Bromus madritensis, and Bromus rubens (Additional file 2, Table 1). Together, these five species made up $45 \%$ of total species cover and $97 \%$ of introduced species by cover; the other seven introduced species (Hirschfeldia incana [L.] Lagr.-Foss., Medicago polymorpha L., Vulpia myuros [L.] C.C. Gmel., Senecio vulgaris L., Erodium botrys [Cav.] Bertol., Hordeum murinum L., and Avena barbata Pott ex Link) made up the remaining 3\% of introduced cover. Only Bromus diandrus, Bromus tectorum, and Erodium cicutarium were found in both survey years. Bromus diandrus was the most dominant introduced species, representing $48 \%$ of introduced species cover in 2004 and 51\% in 2015; Bromus diandrus made up $15 \%$ of total species cover in 2004 and $24 \%$ in 2015 . The next highest species by cover 
in 2004 was Briza maxima, representing 15\% of introduced cover and $5 \%$ of total cover.

\section{Fire history and abiotic factors}

Mean dNBR in 2003 was 301 (range $=-215$ to 758 ), while mean dNBR in 2008 was 158 (range $=-84$ to 670). In 2003, the Old Fire had a mean dNBR of 469 (range = 130 to 758), while the Simi Fire had a mean dNBR of 135 (range $=-215$ to 401 ). After the Sesnon Fire in 2008, the mean dNBR at the Simi sites was 302 (range = -41 to 670 ), while at the Old sites, which did not burn that year, the mean dNBR was -33 (range $=-84$ to 62 ). The range of time between the two most recent fires was the same in 2004 and 2015 (4 to 125 years), although the median dropped from 22 years in 2004 to just 5 years in 2015, primarily due to the Sesnon Fire reburning some of the Simi Fire sites only five years after the Simi Fire. The number of reburns in 2004 ranged from 1 to 5, with a mean of 2.9 burns, and in 2015 ranged from 1 to 6 burns with a mean of 3.4 burns. Rock cover was similar at the Old and Simi fire sites in 2015 with a mean of $7.3 \%$ and $7.2 \%$, respectively, and ranged from 0 to $60 \%$ at the Old Fire sites and 0 to $75 \%$ at the Simi Fire sites (Additional file 1, Fig. 1).

\section{SEM results}

Our initial SEM (Fig. 1) yielded a highly discrepant, singular model (comparative fit index $=0.972$, root mean square error approximation $=0.186$, chi-square $=30.8$, degrees of freedom $=9$, and $P<0.0001)$. Using the residual covariance matrix from the SEM, we were able to retain relationships within this model with high residual covariance. Our final inferential model yielded no significant discrepancies between the model and the data (comparative fit index $=0.997$, root mean square error approximation $=0.036$, chi-square $=30.52$, degrees of freedom $=28$, and $P=0.34$; Fig. 3, Additional file 3, Fig. 1). Many of the direct relationships originally hypothesized for exploration using SEM were not supported by the collected data. The unsupported relationships were excluded from the final inferential model; these excluded relationships were mean annual precipitation not

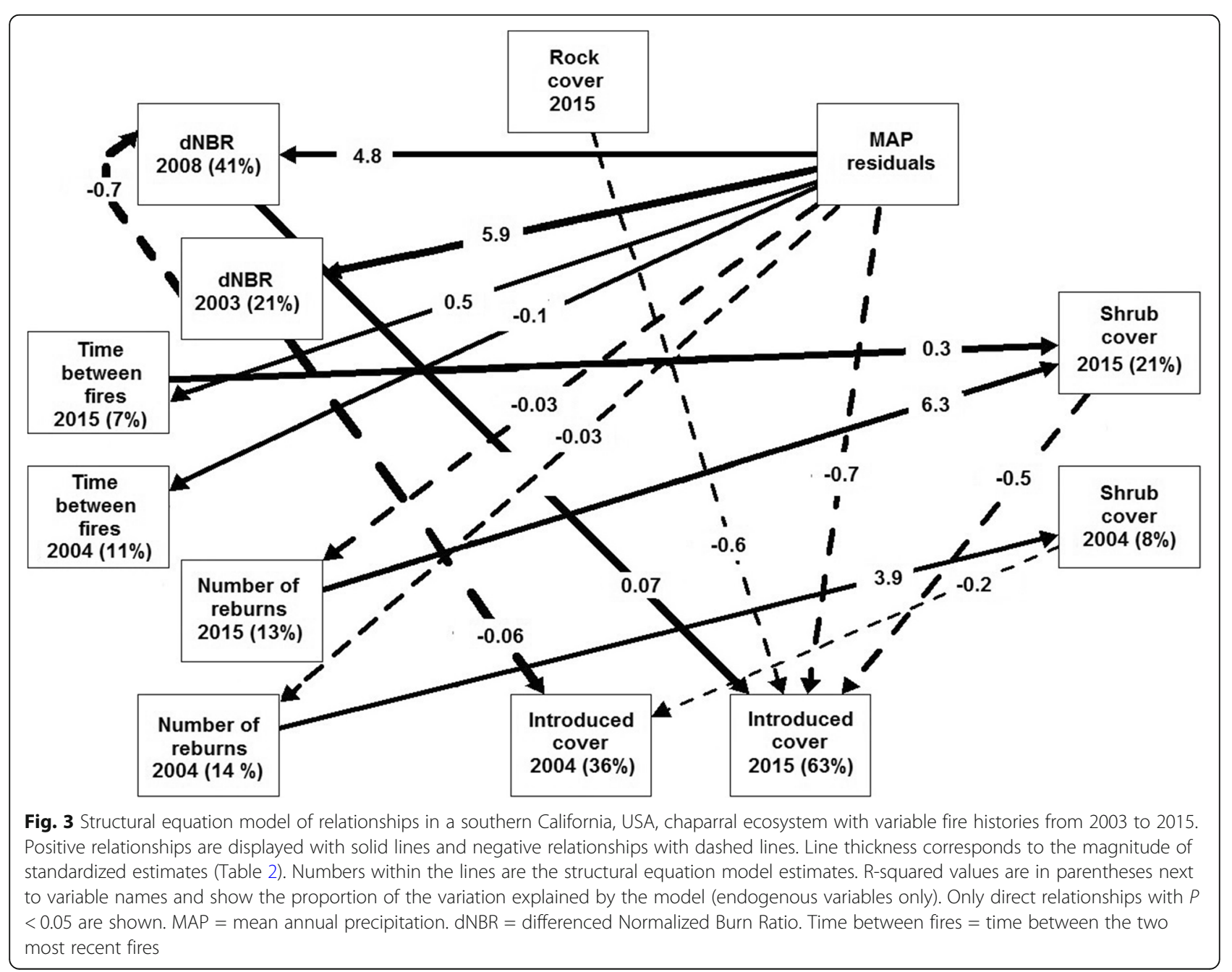


significantly predicting shrub cover in either years nor introduced cover in 2004, rock cover not predicting shrub cover, shrub cover and introduced cover not predicting dNBR or fire history metrics, and, with the exception of 2003, dNBR predicting 2008 dNBR, all relationships between $\mathrm{dNBR}$ and fire history metrics were accounted for in the model's residual covariance structure due to high correlations.

Our model explained $8 \%$ of the variation in shrub cover in 2004, which increased to 21\% by 2015 (Fig. 3). The model explained $35 \%$ and $63 \%$ of the variability in introduced cover in 2004 and 2015, respectively. Based on standardized estimates (Table 2, Fig. 3), the number of reburns was the most influential variable affecting shrub cover in 2004, while the time between fires was most influential variable affecting shrub cover in 2015. The most influential variable affecting introduced cover in 2004 was dNBR in 2003; similarly, introduced cover in 2015 was most influenced by dNBR in 2008 (Table 2, Fig. 3).

Mean annual precipitation, an exogenous variable not predicted by other variables in the model, directly affected dNBR and fire history metrics. Overall, sites that were wetter tended to burn with higher burn severity (Fig. 4A and B), had longer times between the two most recent fires (Fig. 4C and D), burned less frequently (Fig. $4 \mathrm{E}$ and $\mathrm{F}$ ), and had lower invasion by introduced species in 2015 (Fig. 4G) (Table 2). The relationship between mean annual precipitation and introduced cover in 2004 was mediated by dNBR in 2003; sites that were wetter had higher dNBR and lower introduced cover (Fig. 3, Table 3). The relationship between mean annual precipitation and shrub cover in 2004 and 2015 was mediated by the number of reburns in 2004 and 2015 ; wetter sites tended to burn less often, resulting in lower shrub cover (Fig. 3, Table 3). Rock cover in 2015 had a negative, direct effect on introduced cover in 2015 (Fig. 5), but there were no other significant direct or indirect relationships with rock cover in the model (Fig. 3, Table 2).

We found a direct, negative effect of $2003 \mathrm{dNBR}$ on introduced cover in 2004 (Fig. 6A), and a direct positive effect of 2008 dNBR on introduced cover in 2015 (Fig. $6 \mathrm{~B})$. There was a direct negative relationship between 2003 dNBR and 2008 dNBR (Fig. 6C). We also found that this relationship between $2003 \mathrm{dNBR}$ and 2008 dNBR indirectly affected introduced cover in 2015 (Fig. 3, Table 3). Overall, sites in 2003 had higher dNBR than sites in 2008, which resulted in higher introduced cover by 2015 .

Time between the two most recent fires had a positive effect on shrub cover in 2015 (Fig. 7A) but not in 2004 (Fig. 3, Table 2). In both 2004 and 2015, there was not a significant direct or indirect relationship between the introduced cover and time between the two most recent fires (Fig. 3, Table 3). The number of reburns had positive effects on shrub cover in both 2004 and 2015 (Figs. 3 and 7B, C; Table 2). We did not find a significant direct or indirect relationship between the number of reburns in 2004 and 2015 and introduced cover in 2004 and 2015 (Fig. 3, Table 3). For plant-based variables, introduced cover in either year was not predictive of any of the variables in the model (Table 2), although shrub cover in 2004 and 2015 had a significant negative relationship with introduced cover in 2004 (Fig. 8A) and 2015 (Fig. 8B)(Fig. 3, Table 2). Shrub cover did not significantly mediate any indirect relationships between $\mathrm{dNBR}$, fire history, and introduced cover (Table 3).

\section{Discussion}

We predicted that climate would have direct effects on burn severity (dNBR) and fire history metrics, resulting in changes in plant communities. Indeed, mean annual precipitation had direct effects on burn severity and fire history metrics in this study. Wetter sites tended to have higher burn severity, burn less often, and have a longer time between fires, which directly and indirectly affected shrub and introduced cover.

Abiotic and biotic factors influence burn severity, including climate, fuel loads, pre-fire vegetation composition, and time since the last fire (Parks et al. 2015). In many ecosystems, including chaparral, if fire re-occurs before the ecosystem has had adequate time to recover, the severity of the subsequent fire is limited (Parks et al. 2014a, Parks et al. 2015). Indeed, higher burn severity in the first fire resulted in lower burn severity in the subsequent fire, and the maximum burn severity at the 2008 sites was reduced, which we presume was due to lower fuel loads. Also, high mean annual precipitation increased burn severity in both 2003 and 2008, likely due to higher fuel loads in those areas.

Although time between the two most recent fires and the number of reburns are strongly correlated, they have slightly different implications for ecosystems. Time between the two most recent fires impacts stand age, species composition, and invasibility, while the number of reburns affects a site's resiliency to fire (Parks et al. 2014a, Parks et al. 2015). We found that mean annual precipitation increased the time between the two most recent fires. This may be due to increases in live fuel moisture, which has a limiting effect on a site's ability to burn (Dennison and Moritz 2010). Time between the two most recent fires determines how much fuel is available to burn, which in turn significantly influences fire intensity and burn severity. Many shrub species, such as the dominant and perennial Ceanothus oliganthus, Ceanothus megacarpus Nutt., and Adenostoma fasciculatum, can be entirely or nearly eliminated from sites with a 

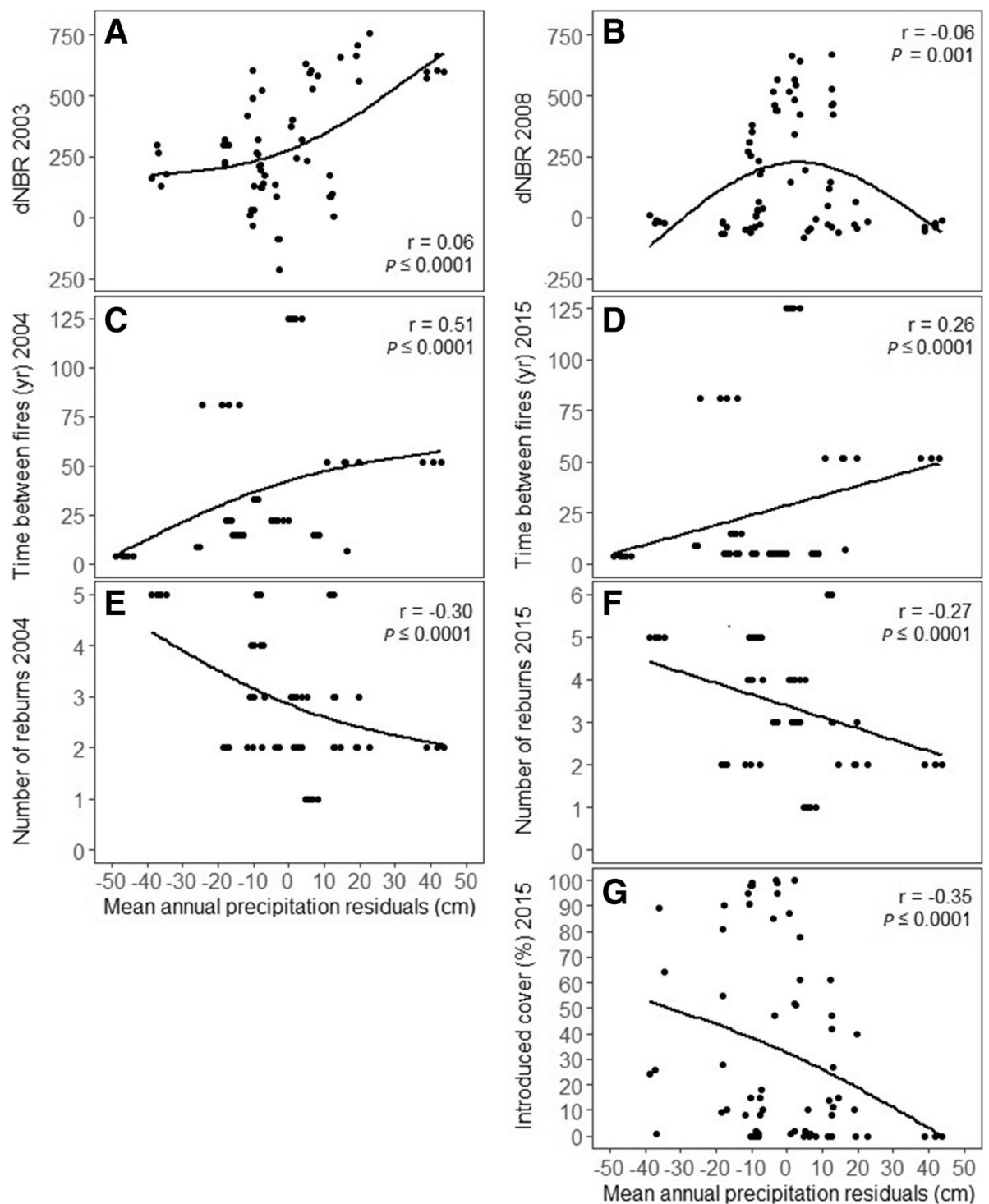

Fig. 4 Significant bivariate relationships found in the Structural Equation Model (SEM) between dNBR, fire history metrics, and mean annual precipitation residuals at the 2003 Simi and Old fires and 2008 Sesnon Fire in southern California, USA. A) burn severity in 2003; B) burn severity in 2008; C) the number of years between the previous most recent two fires as of 2004; D) the number of years between the two most recent fires as of 2015; E) the number of times a site had burned since 1878, tallied in 2004; F) the number of times a site had burned since 1878, tallied in 2015; and G) introduced species cover in 2015. $r$ = Spearman rank correlation coefficients; $P$-values are from the SEM. Time between fires = time between the two most recent fires (years); $d N B R=$ differenced Normalized Burn Ratio

shorter than historic fire return interval (Zedler et al. 1983, Jacobsen et al. 2004). This potential extirpation can be exacerbated by the fact that native obligate seeders such as Ceanothus megacarpus and Ceanothus crassifolius thrive in arid locations where fires have the potential to burn more frequently (Kolb and Davis 1994, Pratt et al. 2014). While short time intervals between fires can be a detriment to the native plant community, introduced grasses with an annual life history strategy can typically survive short intervals between fires (Whisenant 1990).
Lower mean annual precipitation also decreased the number of reburns, acting as a top-down control by increasing live fuel moisture, which limits its ability to burn (Dennison and Moritz 2010), and decreases its invasibility by the more arid-dependent, introduced Bromus species (Germino et al. 2016). In chaparral ecosystems, fine fuels created by high introduced-species cover can increase fire frequency (Keeley 2000). Frequent ground fires can impact native species, as many native shrubs are unable to survive during short fire return intervals caused by frequent burns (Keeley et al. 2003, 
Table 2 Results from structural equation model of variables affecting chaparral ecosystem recovery one and twelve years after the southern California, USA, Old and Simi fires of 2003. Direct relationships with $P<0.05$ in bold and italics; $P<0.10$ in italics; dNBR $=$ differenced Normalized Burn Ratio

\begin{tabular}{|c|c|c|c|c|c|c|c|c|}
\hline Independent variable & Dependent variable & $\begin{array}{l}\text { Model } \\
\text { estimate }\end{array}$ & $\begin{array}{l}\text { Standard } \\
\text { error }\end{array}$ & Z-value & Lower $\mathrm{Cl}$ & Upper Cl & $\begin{array}{l}\text { Standardized } \\
\text { estimate }\end{array}$ & $P$-value \\
\hline Mean annual precipitation & dNBR 2003 & 5.9 & 1.2 & 5.1 & 3.5 & 8.2 & 0.46 & $<0.0001$ \\
\hline Mean annual precipitation & $d N B R 2008$ & 4.8 & 1.4 & 3.5 & 2 & 7.5 & 0.37 & 0.001 \\
\hline Mean annual precipitation & Time between fires 2004 & 0.6 & 0.1 & 4.7 & 0.3 & 0.8 & 0.32 & $<0.0001$ \\
\hline Mean annual precipitation & Time between fires 2015 & 0.5 & 0.1 & 4.3 & 0.3 & 0.8 & 0.27 & $<0.0001$ \\
\hline Mean annual precipitation & Number of fires 2004 & -0.03 & 0.01 & -4.2 & 0 & -0.01 & -0.37 & $<0.0001$ \\
\hline Mean annual precipitation & Number of fires 2015 & -0.03 & 0.01 & -3.9 & 0 & -0.01 & -0.33 & $<0.0001$ \\
\hline Mean annual precipitation & Introduced cover 2015 & -0.7 & 0.2 & -3.9 & -1 & -0.3 & -0.33 & $<0.0001$ \\
\hline Rock 2015 & Introduced cover 2015 & -0.6 & 0.2 & -3.4 & -0.9 & -0.2 & -0.23 & 0.001 \\
\hline Rock 2015 & Shrub cover 2015 & -0.2 & 0.2 & -1.3 & -0.6 & 0.1 & -0.13 & 0.2 \\
\hline$d N B R 2003$ & $d N B R 2008$ & -0.7 & 0.2 & -4.6 & -0.9 & -0.3 & -0.68 & $<0.0001$ \\
\hline dNBR 2003 & Introduced cover 2004 & -0.1 & 0.02 & -2.9 & -0.1 & -0.02 & -0.62 & 0.004 \\
\hline dNBR 2003 & Shrub cover 2004 & 0.01 & 0.01 & 1.3 & -0.01 & 0.02 & 0.13 & 0.2 \\
\hline$d N B R 2008$ & Introduced cover 2015 & 0.1 & 0.01 & 4.8 & 0.04 & 0.1 & 0.44 & $<0.0001$ \\
\hline dNBR 2008 & Shrub cover 2015 & -0.01 & 0.02 & -0.5 & 0 & 0.03 & -0.07 & 0.6 \\
\hline Time between fires 2004 & Introduced cover 2004 & 0.01 & 0.1 & 0.1 & -0.1 & 0.1 & 0.01 & 0.9 \\
\hline Time between fires 2015 & Shrub cover 2015 & 0.3 & 0.1 & 2.1 & 0 & 0.5 & 0.39 & 0.04 \\
\hline Number of fires 2004 & Introduced cover 2004 & -3.9 & 2.7 & -1.5 & -9.1 & 1.1 & -0.23 & 0.1 \\
\hline Number of fires 2004 & Shrub cover 2004 & 3.9 & 1.3 & 3.1 & 1.5 & 6.7 & 0.31 & 0.002 \\
\hline Number of fires 2015 & Shrub cover 2015 & 6.3 & 2.6 & 2.4 & 1 & 11.4 & 0.35 & 0.02 \\
\hline Introduced cover 2004 & Introduced cover 2015 & 0.3 & 0.2 & 1.7 & -0.01 & 0.7 & 0.19 & 0.09 \\
\hline Shrub cover 2004 & Shrub cover 2015 & 0.4 & 0.2 & 1.9 & -0.1 & 0.8 & 0.24 & 0.05 \\
\hline Shrub cover 2004 & Introduced cover 2004 & -0.2 & 0.1 & -2.2 & -0.4 & -0.01 & -0.15 & 0.03 \\
\hline Shrub cover 2015 & Introduced cover 2015 & -0.5 & 0.1 & -4.3 & -0.7 & -0.2 & -0.33 & $<0.0001$ \\
\hline
\end{tabular}

Keeley 2006, Keeley and Brennan 2012, Meng et al. 2014). Thus, introduced species drive increases in fire frequency that may result in community state changes (Zedler et al. 1983).

Few studies have considered long-term plant community dynamics in relation to fire. Although shrub cover remained similar over time, the number of shrub species doubled between 2004 and 2015. The most common shrub species one and twelve years post fire were facultative seeders, with Adenostoma fasciculatum being the most frequently encountered. Shrub diversity, in the first growing season after fire, is primarily attributed to

Table 3 Results from structural equation model of mediating variables affecting chaparral ecosystem recovery one and twelve years after the southern California, USA, Old and Simi fires of 2003. Direct relationships with $P<0.05$ in bold and italics; $P<0.10$ in italics; $\mathrm{dNBR}=$ differenced Normalized Burn Ratio

\begin{tabular}{|c|c|c|c|c|c|c|}
\hline Independent variable & Mediating variable & Dependent variable & Model estimate & Standard error & Z-value & $P$-value \\
\hline Mean annual precipitation & dNBR 2003 & Introduced cover 2004 & -0.35 & 0.13 & -2.65 & 0.01 \\
\hline Mean annual precipitation & Time between fires 2015 & Shrub cover 2015 & 0.15 & 0.08 & 1.84 & 0.07 \\
\hline Mean annual precipitation & Number of reburns 2004 & Shrub cover 2004 & -0.10 & 0.04 & -2.71 & 0.01 \\
\hline Mean annual precipitation & Number of reburns 2015 & Shrub cover 2015 & -0.17 & 0.09 & -1.91 & 0.05 \\
\hline$d N B R 2003$ & $d N B R 2008$ & Introduced cover 2015 & -0.05 & 0.01 & -3.65 & $<0.001$ \\
\hline Time between fires 2015 & Shrub cover 2015 & Introduced cover 2015 & -0.13 & 0.08 & -1.72 & 0.09 \\
\hline Number of reburns 2004 & Shrub cover 2004 & Introduced cover 2004 & -0.76 & 0.46 & -1.63 & 0.10 \\
\hline Number of reburns 2015 & Shrub cover 2015 & Introduced cover 2015 & -2.88 & 1.58 & -1.82 & 0.07 \\
\hline
\end{tabular}




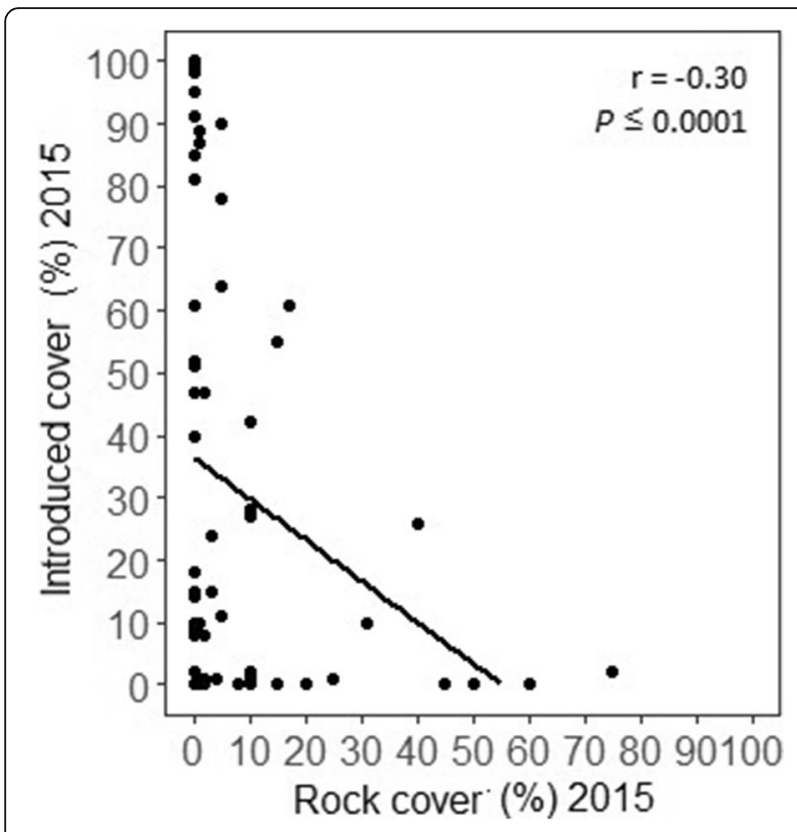

Fig. 5 Significant bivariate relationship found in the Structural Equation Model (SEM) between introduced cover and rock cover in 2015 after the 2003 Simi and Old fires in southern California, USA. $r$ = Spearman rank correlation coefficients; $P$-values are from the SEM

species that survived the fire and those that benefit from fire, such as facultative and obligate seeders and obligate resprouters (Moreno and Oechel 1991). Shrub diversity in chaparral after the second growing season is a dynamic process reliant on spatial patterns of resources, especially precipitation (Keeley et al. 2005b). The number of introduced species doubled over twelve years, with Bromus diandrus consistently common over that period. Keeley et al. (2005a) found that introduced species diversity peaked two to five years post fire, although they only studied the first five years post fire. Our results suggest that regardless of when introduced species diversity peaks, numerous introduced species can maintain a population over time.

As predicted, we found that the direct relationships between mean annual precipitation and fire had indirect consequences on plant communities, but these were not consistent across time, burn severity, fire history, or plant functional groups. First, the number of reburns was lower in areas of high precipitation, which resulted in lower shrub cover both one and twelve years post fire. Furthermore, we found that areas with high precipitation also had high burn severity, which resulted in lower introduced cover, but this indirect relationship was only significant one year after fire. We also found that shrub species and not introduced species benefited when sites had a longer than average time between fires, although this was only evident twelve years post fire, not one year post fire.
Rock cover affects percolation and thus site hydrology (Urbanek and Shakesby 2009); creates a more heterogeneous surface that may limit post-fire erosion (Shakesby et al. 1994); provides microsites for seed germination (Schlesinger and Gill 1978); and alters soil nutrients (Houlton et al. 2018). Additionally, species richness has been found to be positively associated with rock cover in chaparral ecosystems (Grace and Keeley 2006). There were no significant relationships between rock cover and burn severity or fire history metrics in this study. However, similar to Keeley et al. (2005d), who found a negative relationship between rock and introduced cover one, two, and five years post fire, we found that rock cover decreased introduced cover but only twelve years post fire. We also found that this relationship between rock and introduced cover was most likely masked by a significant relationship between burn severity and introduced cover, as did Keeley et al. (2005d). In our study, during the first growing season, burn severity had such a significant impact on introduced cover that there was little room for other influences. These results suggest that rock cover can have an impact on introduced cover, and the timing and magnitude of these effects depend on other environmental variables.

Introduced cover was also affected by mean annual precipitation, burn severity, fire history metrics, and shrub cover, resulting in complex interactions. Higher mean annual precipitation decreased introduced cover in year twelve, which is not surprising given that our sites were predominantly invaded by Bromus species, which flourish in more arid ecosystems (Germino et al. 2016). However, we did not find that mean annual precipitation influenced introduced cover during the first growing season after fire, which we attribute to low introduced cover during the first year, and colonization, which usually peaks two to five years post fire (Keeley et al. 2005a).

The positive effects of mean annual precipitation on burn severity immediately after fire resulted in lower introduced cover one year after fire. Others have found that higher severity favors shrub species, which can then outcompete introduced species (Keeley et al. 2005d). However, the positive effects of mean annual precipitation on 2003 burn severity reduced 2008 burn severity, and thus increased introduced cover in year twelve. Higher burn severity in year one likely reduced fuel. Combined with a shorter fire return interval of five years, which was likely detrimental to native shrubs, this allowed introduced species to increase after two successive burns. Surprisingly, time between the two most recent fires and number of reburns had no direct effects on introduced cover. 


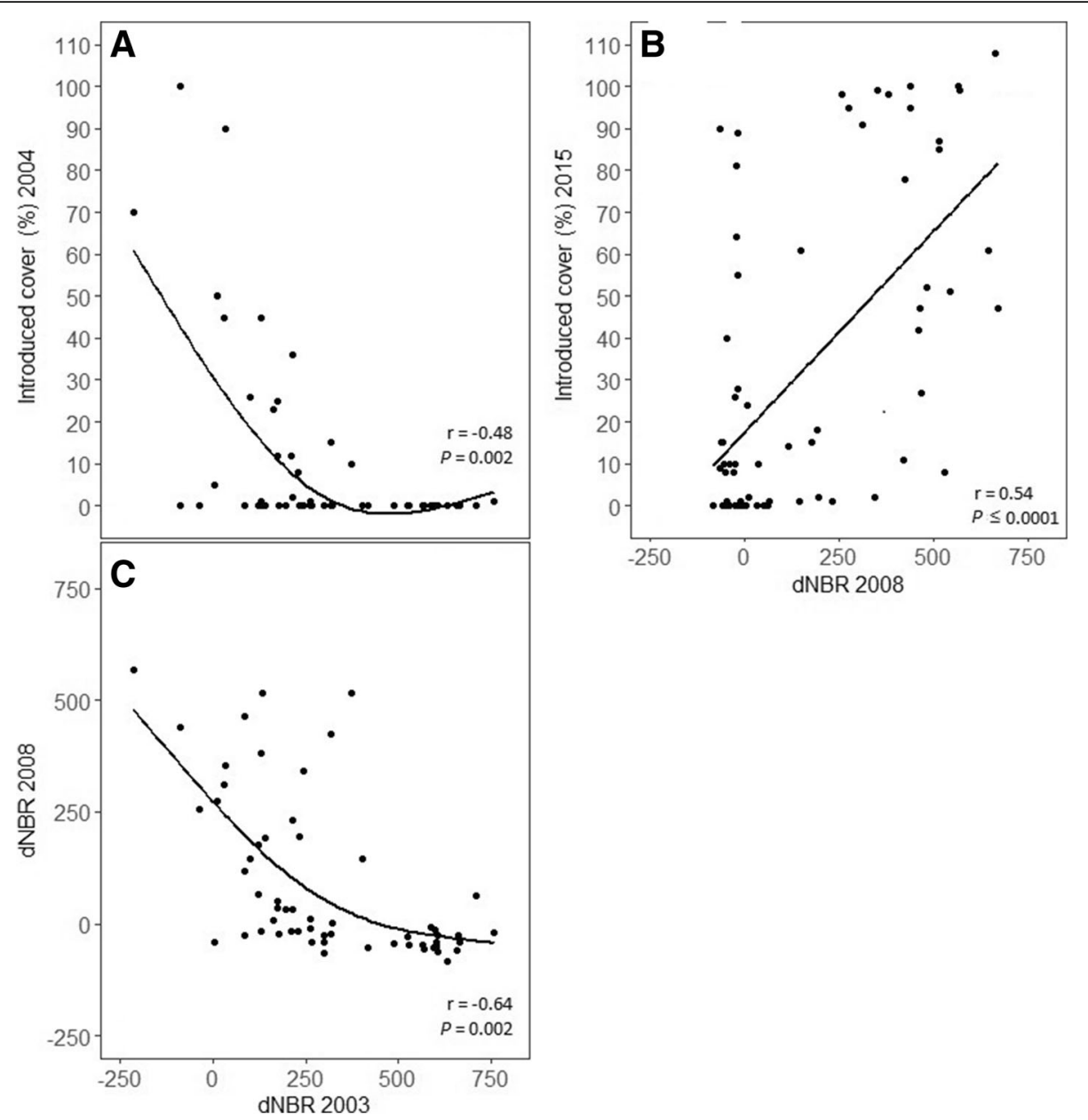

Fig. 6 Significant bivariate relationships found in the Structural Equation Model (SEM) between 2003 and 2008 differenced Normalized Burn Ratio (dNBR) after the Simi, Old, and Sesnon fires in southern California, USA. A) introduced species cover in 2004; B) introduced species cover in 2015; and C) burn severity (dNBR) after the 2008 Sesnon Fire. $r$ = Spearman rank correlation coefficients; $P$-values are from the SEM

Climate and fire effects on introduced cover were mediated through shrub cover. Like others, we found that shrub cover reduced introduced cover (Keeley and Brennan 2012, Condon and Pyke 2018), often through complex interactions with precipitation, burn severity, and fire history metrics. Overall, sites that had longer time between fires and more reburns had higher shrub cover, simliar to what others have found. Zedler et al. (1983) showed that longer time between fires benefit native shrubs, and McMichael et al. (2004) used remote sensing to show that leaf area index is maximized at 15 years post fire, a timeline similar to our study. These results suggest that the sites in our study were within the normal range of variability for time between fires and number of reburns. This study's results do not refute the cause for concern that Zedler et al. (1983) addressed, which was that reburning frequency higher than observed in this study could lead to a state change, due to shrubs being less tolerant than introduced species to more frequent fires.

\section{Conclusions}

Post-fire ecology studies typically focus on the direct relationship between fire metrics and plant community within five years after fire. Our study was unique in that it compared these direct relationships, as well as indirect relationships, between burn severity, time between the two most recent fires, number of reburns, climate, abiotic variables, and the plant community during the first and twelfth growing season after fire, and across variable fire histories. We found that mean annual precipitation was a driving factor in chaparral fire regimes, generally resulting in positive effects on native shrubs and adverse effects on introduced species. Thus, changes to climate will result in changes in chaparral fire regimes, which may have negative consequences for native species. We found that these 

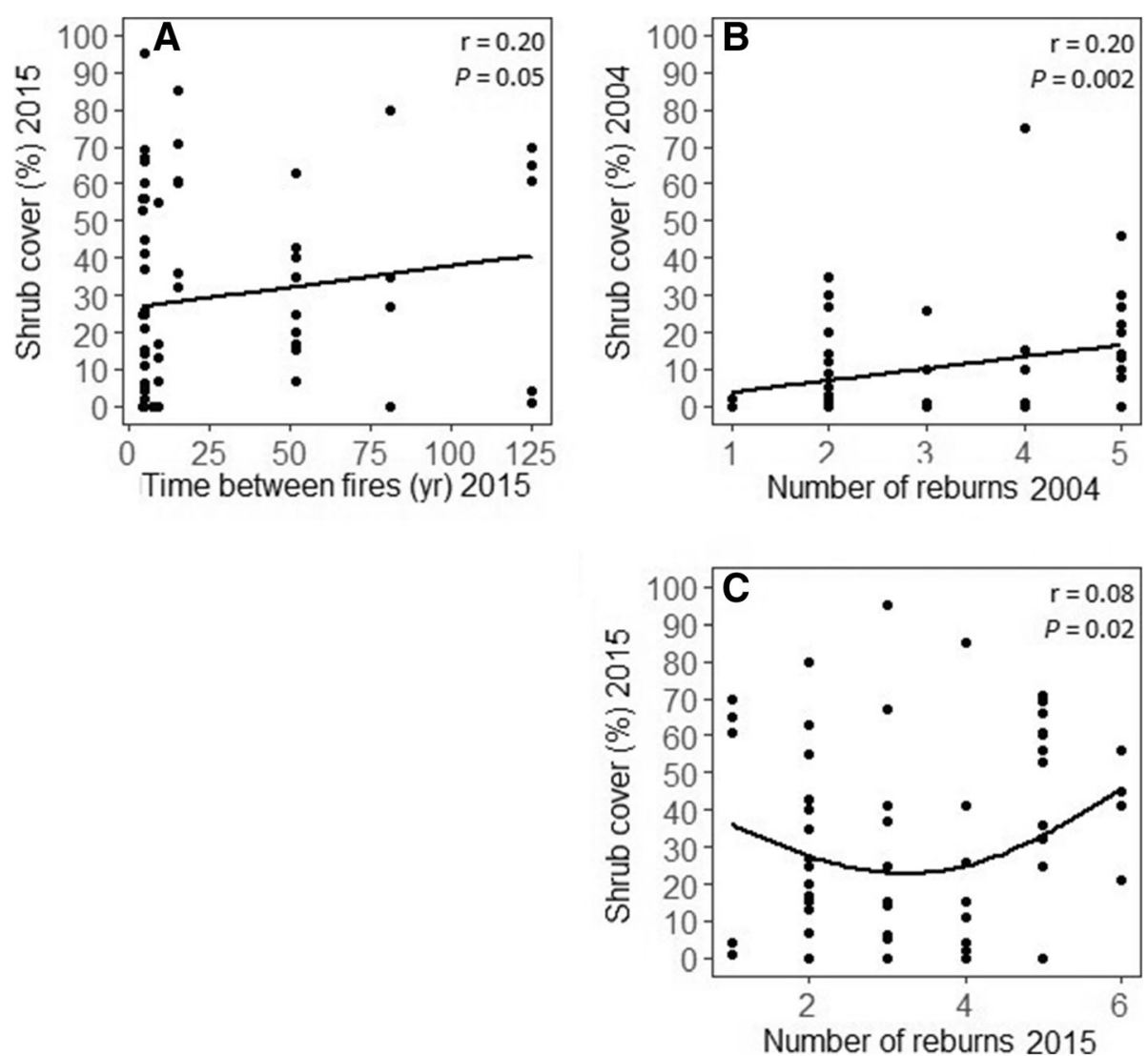

Fig. 7 Significant bivariate relationships found in the Structural Equation Model (SEM) after the 2003 southern California, USA, Simi and Old fires between number of reburns, time between the two most recent fires, and shrub cover. A) shrub species cover in 2015; B) shrub species cover in 2004; and C) shrub species cover in 2015. r = Spearman rank correlation coefficients; P-values are from the SEM
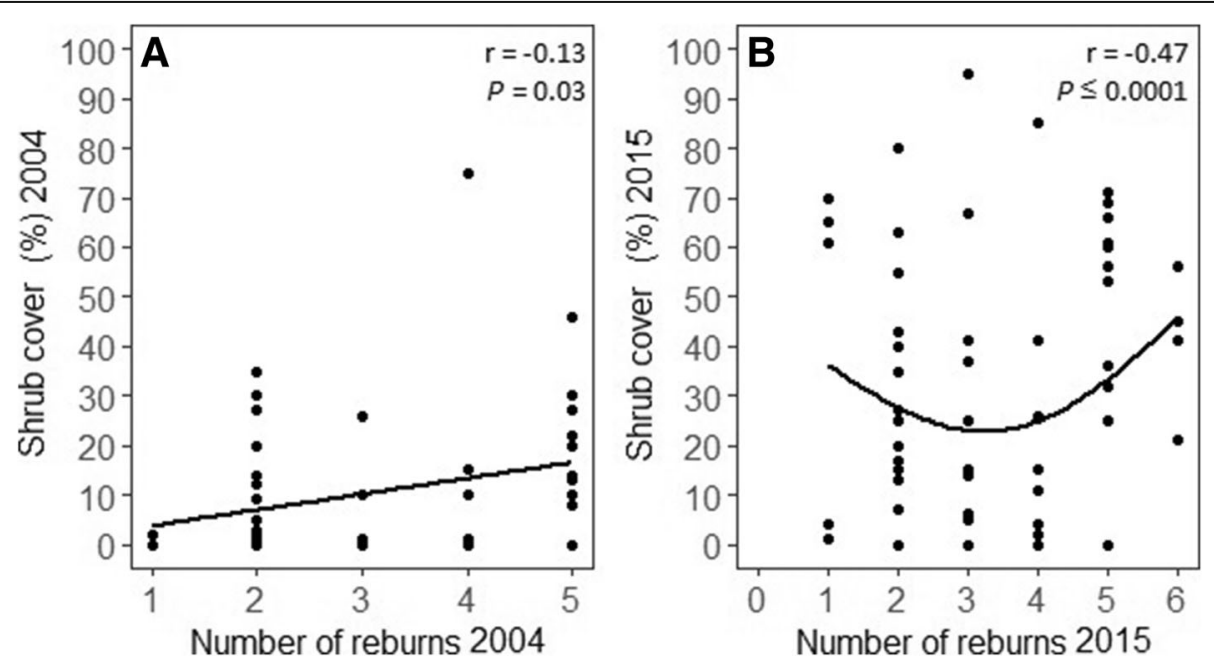

Fig. 8 Significant bivariate relationships found in the Structural Equation Model (SEM) between introduced cover and shrub cover in A) 2004 and B) 2015 after the 2003 Old and Sesnon fires in southern California, USA. $r$ = Spearman rank correlation coefficients; P-values are from the SEM 
fire effects on native and introduced species changed over time, implying that long-term monitoring is essential for understanding the successional trajectory of a chaparral site. This may be especially true at sites that receive precipitation outside (more likely less than) the normal range of variability. Finally, we found that shrub cover was negatively associated with introduced cover, which are both influenced by burn severity, either directly or indirectly, suggesting dynamic competitive exclusion between shrubs and introduced species.

\section{Additional files}

Additional file 1: Distribution of variables obtained after the Old, Simi, and Sesnon fires in southern California, USA. A) number of reburns since 1878; B) number of years between the most recent two fires; C) burn severity one year after the 2003 Old and Simi fires and one year after the 2007 Sesnon Fire; D) percent shrub species cover; E) percent introduced species cover; and F) percent rock cover. Rock cover in 2004 was the only variable shown that was not included in the structural equation model; it does not differ significantly from 2015 rock cover. Vertical dashed line indicates the mean. $P$-values are from paired Wilcoxen signed rank tests with continuity correction between years. (JPG $138 \mathrm{~kb}$ )

Additional file 2 : Species percent mean cover found one year and twelve years post fire at the $2003 \mathrm{Simi}$ and Old fires in southern California, USA. Native status: $\mathrm{N}=$ native plant, $\mathrm{I}=$ introduced plant, $\mathrm{U}=$ unknown status. (DOCX $45 \mathrm{~kb}$ )

Additional file 3: Structural equation model of the final model's significantly correlated error relationships only. Data used in the model was collected one and twelve years after the 2003 Old and Simi fires in southern California, USA. Positive relationships are displayed with solid lines and negative relationships with dashed lines. Line thickness corresponds to the magnitude of standardized estimates. Numbers within the lines are covariance estimates. R-squared values are in parentheses next to variable names and show the proportion of the variation explained by the model (endogenous variables only). Only correlated errors with $P<0.05$ are shown. Variables with insignificant correlated errors are displayed with no arrows. (JPG $92 \mathrm{~kb}$ )

\section{Acknowledgements}

Thanks to J. Byrne, M. Schmidt, D. Hammond, J. Bontrager, S. McNeal, and E. Berman for collecting 2015 field data, and to L. Lentile and D. Roberts for the 2004 plant data collection and identification. Thanks to C. Dencker for statistical advice. Thanks to C. Dencker and K. Tonkel for reviewing the manuscript.

\section{Funding}

This project was funded by the Joint Fire Science Program (project \# 14-102-27).

\section{Availability of data and materials}

The datasets used and analyzed during this study are available from https:// doi.org/10.2737/RDS-2019-0005

\section{Authors' contributions}

AS conceived, designed, and performed the data analysis and wrote the manuscript; BN and AH contributed to the conceptual ideas, experimental design, data collection, and writing; BB contributed towards the experimental design, data collection, and writing. All authors read and approved the final manuscript.

\section{Ethics approval and consent to participate}

Not applicable.

\section{Consent for publication}

Not applicable.

\section{Competing interests}

The authors declare that they have no competing interests.

\section{Publisher's Note}

Springer Nature remains neutral with regard to jurisdictional claims in published maps and institutional affiliations.

\section{Author details}

'USDA Agricultural Research Service, Great Basin Rangelands Research Unit, 920 Valley Road, Reno, Nevada 89512, USA. ${ }^{2}$ USDA Forest Service, Rocky Mountain Research Station, 1221 South Main Street, Moscow, ID 83843, USA.

Received: 2 October 2018 Accepted: 20 February 2019

Published online: 29 April 2019

\section{References}

Bachelet, D., K. Ferschweiler, T. Sheehan, and J. Strittholt. 2016. Climate change effects on southern California deserts. Journal of Arid Environments 127: 1729. https://doi.org/10.1016/j.jaridenv.2015.10.003

Bond, W.J., and J.E. Keeley. 2005. Fire as a global 'herbivore': the ecology and evolution of flammable ecosystems. Trends in Ecology \& Evolution 20: 387394. https://doi.org/10.1016/.t.tree.2005.04.025

Borchert, M.I., and D.C. Odion. 1995. Fire intensity and vegetation recovery in chaparral: a review. Pages 91-101 in: J. Keeley and T. Scott, editors. Brushfires in California wildlands: ecology and resource management. International Association of Wildland Fire, Fairfield, Washington, USA.

Bright, B.C., A.T. Hudak, E.K. Strand, B.A. Newingham, A.G. Smith, D. H. Hammond, J.M. Dodge, J. Bontrager. 2019. Field attributes and satellite data for "How vegetation recovery and fuel conditions in past fires influences fuels and future fire management in five western US ecosystems". Forest Service Research Data Archive, Fort Collins, Colorado, USA. https://doi.org/10.2737/ RDS-2019-0005

CalFire [California Department of Forestry and Fire Protection]. 2017. Fire and Resource Assessment Program fire history database. http://frap.fire.ca.gov/ data/frapgisdata-sw-fireperimeters download. Accessed 19 Jan 2018.

Clark, J., A. Parsons, T. Zajkowski, and K. Lannom. 2003. Remote sensing imagery support for Burned Area Emergency Response teams on 2003 southern California wildfires. USDA Forest Service, Remote Sensing Applications Center Project Report RPT1, Salt Lake City, Utah, USA.

Condon, L.A., and D.A. Pyke. 2018. Fire and grazing influence site resistance to Bromus tectorum through their effects on shrub, bunchgrass and biocrust communities in the Great Basin (USA). Ecosystems 21(7): 1416-1431. https:// doi.org/10.1007/s10021-018-0230-8

D'Antonio, C.M., and P.M. Vitousek. 1992. Biological invasions by exotic grasses, the grass/fire cycle, and global change. Annual Review of Ecology and Systematics 23: 63-87. https://doi.org/10.1146/annurev.es.23.110192.000431

Davis, F.W., and J. Michaelsen. 1995. Sensitivity of fire regime in chaparral ecosystems to climate change. Pages 435-456 in: J.M. Moreno and W.C. Oechel, editors. Global change and mediterranean-type ecosystems. Springer, New York, New York, USA. https://doi.org/10.1007/978-1-4612-4186-7_21

Dell, J.E., L.A. Richards, J.J. O'Brien, E.L. Loudermilk, A.T. Hudak, S.M .Pokswinski, B. C. Bright, J.K. Hiers, B.W. Williams, and L.A. Dyer. 2017. Overstory-derived surface fuels mediate plant species diversity in frequently burned longleaf pine forests. Ecosphere 8(10): e01964. https://doi.org/10.1002/ecs2.1964

Dennison, P.E., and M.A. Moritz. 2010. Critical live fuel moisture in chaparral ecosystems: a threshold for fire activity and its relationship to antecedent precipitation. International Journal of Wildland Fire 18: 1021-1027. https://doi. org/10.1071/WF08055

Farr, T.G. P.A. Rosen, E. Caro, R. Crippen, R. Duren, S. Hensley, M. Kobrick, M. Paller, E. Rodriguez, L. Roth, D. Seal, S. Shaffer, J. Shimada, J. Umland, M. Werner, M. Oskin, D. Burbank, and D. Alsdorf. 2007. The Shuttle Radar Topography Mission. Reviews of Geophysics 45(2): RG2004. https://doi.org/10.1029/ 2005RG000183

Germino, M.J., J. Belnap, J.M. Stark, E.B. Allen, and B.M. Rau. 2016. Ecosystem impacts of exotic annual invaders in the genus Bromus. Pages 61-95 in: M. Germino, J. Chambers, and C. Brown, editors. Exotic brome-grasses in arid and semiarid ecosystems of the western US. Springer, Cham, Switzerland. https://doi.org/10.1007/978-3-319-24930-8_3

Grace, J.B. 2006. Structural equation modeling and natural systems. Cambridge University Press, Cambridge, England, United Kingdom. https://doi.org/10 1017/CBO9780511617799. 
Grace, J.B., and J.E. Keeley. 2006. A structural equation model analysis of postfire plant diversity in California shrublands. Ecological Applications 16: 503-514. https://doi.org/10.1890/1051-0761(2006)016[0503:ASEMAO]2.0.CO;2

Houlton, B.Z., S.L. Morford, and R.A. Dahlgren. 2018. Convergent evidence for widespread rock nitrogen sources in Earth's surface environment. Science 360: 58-62. https://doi.org/10.1126/science.aan4399

Hudak, A., P. Morgan, M.J. Bobbitt, A.M.S. Smith, S.A. Lewis, L.B. Lentile, P.R. Robichaud, J.T. Clark, and R.A. McKinley. 2007. The relationship of multispectral satellite imagery to immediate fire effects. Fire Ecology 3: 64-90. https://doi.org/10.4996/fireecology.0301064

Hutchinson, M.F. 2000. ANUSPLIN user guide version 4.1. Centre for Resource and Environmental Studies, Australian National University, Canberra, Australia.

Jacobsen, A.L., S.D. Davis, and S.L. Fabritius. 2004. Fire frequency impacts nonsprouting chaparral shrubs in the Santa Monica Mountains of southern California. In: M. Arianoutsou and V.P. Papanastasis, editors. Proceedings of the 10th MEDECOS conference--Ecology, conservation and management of Mediterranean climate ecosystems, 25 April to 1 May 2004, Rhodes, Greece. Millpress, Rotterdam, Netherlands.

Keeley, J.E. 2000. Fire and invasive species in mediterranean-climate ecosystems of California. Pages 81-94 in: K.E.M. Galley and T.P. Wilson, editors. Proceedings of the invasive species workshop: the role of fire in the control and spread of invasive species. Fire conference 2000: the first national congress on fire ecology, prevention, and management. Tall Timbers Research Station, Tallahassee, Florida, USA.

Keeley, J.E. 2006. Fire management impacts on invasive plants in the western United States. Conservation Biology 20(3): 75-384. https://doi.org/10.1111/j. 1523-1739.2006.00339.x

Keeley, J.E., M. Baer-Keeley, and C.J. Fotheringham. 2005d. Alien plant dynamics following fire in mediterranean-climate California shrublands. Ecological Applications 15: 2109-2125. https://doi.org/10.1890/04-1222

Keeley, J.E., and T.J. Brennan. 2012. Fire-driven alien invasion in a fire-adapted ecosystem. Oecologia 169: 1043-1052. https:/doi.org/10.1007/s00442-012-2253-8.

Keeley, J.E., T.J. Brennan, and A.H. Pfaff. 2008. Fire severity and ecosystem responses following crown fires in California shrublands. Ecological Applications 18: 1530-1546. https://doi.org/10.1890/07-0836.1

Keeley, J.E., and C.J. Fotheringham. 2001. Historic fire regime in southern California shrublands. Conservation Biology 15: 1536-1548. https://doi.org/10. 1046/j.1523-1739.2001.00097.x

Keeley, J.E., C.J. Fotheringham, and M. Baer-Keeley. 2005a. Determinants of postfire recovery and succession in mediterranean-climate shrublands of California. Ecological Applications 15: 1515-1534. https://doi.org/10.1890/04-1005

Keeley, J.E., C.J. Fotheringham, and M. Baer-Keeley. 2005b. Factors affecting plant diversity during post-fire recovery and succession of mediterranean-climate shrublands in California, USA. Diversity and Distributions 11(6): 525-537. https:// doi.org/10.1111/j.1366-9516.2005.00200.x

Keeley, J.E., D. Lubin, and C.J. Fotheringham. 2003. Fire and grazing impacts on plant diversity and alien plant invasions in the southern Sierra Nevada. Ecological Applications 13: 1355-1374. https://doi.org/10.1890/02-5002

Keeley, J.E., J.G. Pausas, P.W. Rundel, W.J. Bond, and R.A. Bradstock. 2011. Fire as an evolutionary pressure shaping plant traits. Trends in Plant Science 16: 406411. https://doi.org/10.1016/j.tplants.2011.04.002

Keeley, J.E., A.H. Pfaff, and H.D. Safford. 2005c. Fire suppression impacts on postfire recovery of Sierra Nevada chaparral shrublands. International Journal of Wildland Fire 14: 255-265. https://doi.org/10.1071/WF05049

Kolb, K.J., and S.D. Davis. 1994. Drought tolerance and xylem embolism in cooccurring species of coastal sage and chaparral. Ecology 75(3): 648-659. https://doi.org/10.2307/1941723

Lentile, L.B., P. Morgan, A.T. Hudak, M.J. Bobbitt, S.A. Lewis, A. Smith, and P.R. Robichaud. 2007. Post-fire burn severity and vegetation response following eight large wildfires across the western United States. Fire Ecology 3: 91-108. https://doi.org/10.4996/fireecology.0301091

McMichael, C.E., A.S. Hope, D.A. Roberts, and M.R. Anaya. 2004. Post-fire recovery of leaf area index in California chaparral: a remote sensing-chronosequence approach. International Journal of Remote Sensing 25: 4743-4760. https://doi. org/10.1080/01431160410001726067

Meng, R., P.E. Dennison, C.M. D'Antonio, and M.A. Moritz. 2014. Remote sensing analysis of vegetation recovery following short-interval fires in southern California shrublands. PLoS ONE 9 (10): e110637. https://doi.org/10.1371/ journal.pone.0110637

Molinari, N.A., E.C. Underwood, J.B. Kim, and H.D. Safford. 2018. Climate change trends for chaparral. Pages 385-409 in: E. Underwood, H. Safford, N. Molinari and J. Keeley, editors. Valuing chaparral. Springer, Cham, Switzerland. https://doi.org/10.1007/978-3-319-68303-4_14

Moreno, J.M., and W.C. Oechel. 1991. Fire intensity effects on germination of shrubs and herbs in southern California chaparral. Ecology 72: 1993-2004. https://doi.org/10.2307/1941554

Moritz, M.A. 2003. Spatiotemporal analysis of controls on shrubland fire regimes: age dependency and fire hazard. Ecology 84: 351-361. https://esajournals. onlinelibrary.wiley.com/doi/10.1890/0012-9658\%282003\%29084\%5B0351\% 3ASAOCOS\%5D2.0.CO\%3B2

Odion, D.C., and F.W. Davis. 2000. Fire, soil heating, and the formation of vegetation patterns in chaparral. Ecological Monographs 70: 149-169. https:// esajournals.onlinelibrary.wiley.com/doi/abs/10.1890/0012-9615(2000)070\% 5B0149:FSHATF\%5D2.0.CO\%3B2

Parks, S.A., L.M. Holsinger, C. Miller, and C.R. Nelson. 2015. Wildland fire as a selfregulating mechanism: the role of previous burns and weather in limiting fire progression. Ecological Applications 25: 1478-1492. https://doi.org/10. 1890/14-1430.1

Parks, S.A., C. Miller, C.R. Nelson, and Z.A. Holden. 2014a. Previous fires moderate burn severity of subsequent wildland fires in two large western US wilderness areas. Ecosystems 17: 29-42. https://doi.org/10.1007/s10021-013-9704-x

Parks, S.A., M.-A. Parisien, C. Miller, and S.Z. Dobrowski. 2014b. Fire activity and severity in the western US vary along proxy gradients representing fuel amount and fuel moisture. PLOS ONE 9 (6): e99699. https://doi.org/10.1371/ journal.pone.0099699

Plant, R.E. 2012. Spatial data analysis in ecology and agriculture using R. CRC Press, Boca Raton, Florida, USA.

Pratt, R.B., A.L. Jacobsen, A.R. Ramirez, A.M. Helms, C.A. Traugh, M.F. Tobin, M.S. Heffner, and S.D. Davis. 2014. Mortality of resprouting chaparral shrubs after a fire and during a record drought: physiological mechanisms and demographic consequences. Global Change Biology 20(3): 893-907. https:// doi.org/10.1111/gcb.12477

$\mathrm{R}$ Core Team. 2018. $R$ : a language and environment for statistical computing. $\mathrm{R}$ Foundation for Statistical Computing, Vienna, Austria.

Rehfeldt, G.E. 2006. A spline model of climate for the western United States. In USDA Forest Service General Technical Report RMRS-GTR-165, Rocky Mountain Research Station, Fort Collins, Colorado, USA.

Rehfeldt, G.E., J.J. Worrall, S.B. Marchetti, and N.L. Crookston. 2015. Adapting forest management to climate change using bioclimate models with topographic drivers. Forestry: An International Journal of Forest Research 88(5): 528-539. https://doi.org/10.1093/forestry/cpv019

Roberts, D.W., and S.V. Cooper. 1989. Concepts and techniques of vegetation mapping. 90-96 in: D. Ferguson, P. Morgan, and F.D. Johnson, editors. Land classification based on vegetation: applications for resource management. USDA Forest Service General Technical Report INT-257, Intermountain Research Station, Ogden, Utah, USA.

Rosseel, Y. 2012. lavaan: an R package for structural equation modeling. Journal of Statistical Software 48: 1-36.

Schlesinger, W.H., and D.S. Gill. 1978. Demographic studies of the chaparral shrub, Ceanothus megacarpus, in the Santa Ynez Mountains, California. Ecology 59: 1256-1263. https://doi.org/10.2307/1938239

Shakesby, R.A., C.D.O. Coelho, A.D. Ferreira, J.P. Terry, and R.P.D. Walsh. 1994. Fire, post-burn land management practice and soil erosion response curves in eucalyptus and pine forests, north-central Portugal. Pages 111-132 in: M. Sala and J.L. Rubio, editors. Soil erosion and degradation as a consequence of forest fires. Geoforma Ediciones, Logroño, Spain.

Syphard, A.D., T.J. Brennan, and J.E. Keeley. 2018a. Chaparral landscape conversion in southern California. Pages 311-334 in: E.C. Underwood, H.D. Safford, N.A. Molinari, and J.E. Keeley, editors. Valuing chaparral. Springer, Cham, Switzerland. https://doi.org/10.1007/978-3-319-68303-4_12

Syphard, A.D., T.J. Brennan, and J.E. Keeley. 2018b. Drivers of chaparral type conversion to herbaceous vegetation in coastal southern California. Diversity and Distributions 25(1): 90-101. https://doi.org/10.1111/ddi.12827

Urbanek, E., and R.A. Shakesby. 2009. Impact of stone content on water movement in water-repellent sand. European Journal of Soil Science 60(3): 412-419. https://doi.org/10.1111/j.1365-2389.2009.01128.x

USDA NRCS [US Depatment of Agriculture Natural Resources Conservation Service]. 2016. PLANTS database. https://plants.usda.gov/ Accessed 8 Feb 2016.

Van de Water, K.M., and H.D. Safford. 2011. A summary of fire frequency estimates for California vegetation before Euro-American settlement. Fire Ecology 7(3): 26-58. https://doi.org/10.4996/fireecology.0703026 
Whisenant, S.G. 1990. Changing fire frequencies on Idaho's Snake River Plains: ecological and management implications. Pages 4-10 in: E.D. McArthur, E.M. Romney, S.D. Smith, and P.T. Tueller, editors. Proceedings of the symposium on cheatgrass invasion, shrub die-off, and other aspects of shrub biology and management. USDA Forest Service General Technical Report INT-GTR276, Intermountain Research Station, Ogden, Utah, USA.

Zedler, P.H., C.R. Gautier, and G.S. McMaster. 1983. Vegetation change in response to extreme events: the effect of a short interval between fires in California chaparral and coastal shrub. Ecology 64(4): 809-818. https://doi.org/10.2307/ 1937204

\section{Submit your manuscript to a SpringerOpen ${ }^{\circ}$ journal and benefit from:}

- Convenient online submission

- Rigorous peer review

- Open access: articles freely available online

- High visibility within the field

- Retaining the copyright to your article

Submit your next manuscript at $\boldsymbol{\Delta}$ springeropen.com 